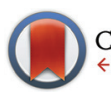

CrossMark \&lick for updates

Cite this: Org. Biomol. Chem., 2015, 13, 5765

Received 7th March 2015 Accepted 13th April 2015

DOI: 10.1039/c5ob00460h www.rsc.org/obc

\section{Synthesis of new carolacton derivatives and their activity against biofilms of oral bacteria $\uparrow$}

\author{
N. Stumpp, $\neq^{a}$ P. Premnath, $t^{b}$ T. Schmidt, ${ }^{c}$ J. Ammermann, ${ }^{c}$ G. Dräger, ${ }^{c}$ M. Reck, ${ }^{b}$ \\ R. Jansen, ${ }^{d}$ M. Stiesch, ${ }^{* a}$ I. Wagner-Döbler ${ }^{* b}$ and A. Kirschning ${ }^{{ }^{c}}$
}

\section{Introduction}

Biofilm-associated infections are a significant problem in medical treatment. ${ }^{1,2}$ These bacterial communities evade host defenses and are inherently resistant to antimicrobial agents whether they grow on natural surfaces like teeth or on synthetic surfaces like medical devices and implants. Bacteria in biofilms can be up to a several hundred fold more resistant to antibiotics than planktonic bacteria. ${ }^{3-5}$ Moreover, there is a great need for new therapeutic strategies, as antibiotic resistance has greatly increased. Thus, natural products with novel modes of action are a promising alternative and a necessity to existing antibiotics.

\footnotetext{
${ }^{a}$ Department of Prosthetic Dentistry and Biomedical Materials Science, Hannover Medical School, Carl-Neuberg-Strasse 1, 30625 Hannover, Germany.

E-mail: Stiesch.Meike@mh-hannover.de,Stumpp.Nico@mh-hannover.de

${ }^{b}$ Helmholtz-Center for Infection Research, Department of Microbial Communication, Inhoffenstr. 7, 38124 Braunschweig, Germany

${ }^{c}$ Institute of Organic Chemistry and Center of Biomolecular Drug Research (BMWZ), Leibniz Universität Hannover, Schneiderberg 1B, 30167 Hannover, Germany. E-mail: andreas.kirschning@oci.uni-hannover.de

${ }^{d}$ Helmholtz-Center for Infection Research, Department of Microbial Drugs, Inhoffenstr. 7, 38124 Braunschweig, Germany

$\dagger$ Electronic supplementary information (ESI) available: Analytical and spectroscopic data including copies of NMR spectra of synthetic intermediates and new carolacton derivatives as well as copies of NMR spectra of all new compounds can be found with this article online. Additionally it contains live/dead measurements and fluorescence microscopic analyses of carolacton against $S$. oralis and $S$. gordonii, MS spectra of reextractions and the quantification of streptococci biofilms after active compound treatment using crystal violet staining. See DOI: 10.1039/c5ob00460h

$\$$ These authors contributed equally.
}

The ongoing exploration of the human microbiome has identified the oral cavity as one of the most diversely populated habitats in the human body. ${ }^{6}$ About 700 species have already been identified in this bacterial community ${ }^{7}$ and many of them have never been cultivated until now. Bacteria usually colonize the oral cavity by forming multispecies biofilms ("plaque"), attached to accessible surfaces. Streptococcal species such as Streptococcus gordonii and $S$. oralis play an integral role in this process. As early colonizers, they provide attachment sites for mid and late colonizers, thus essentially influencing the subsequent stages of oral biofilm formation. ${ }^{8}$ In health, the host and its bacterial commensals coexist symbiotically. ${ }^{9-11}$ Environmental perturbations can disturb this homeostasis and, as a consequence, pathogenic biofilms can evolve. These cause a multitude of inflammatory processes in the oral cavity, including tooth decay and periodontal diseases, the most prevalent infections in the industrialized world. ${ }^{12}$

Dental caries is characterized by a shift in the microbial community towards acid tolerant and aciduric bacteria. These communities are dominated by gram-positive streptococci such as $S$. mutans. ${ }^{13,14}$ Due to the accumulation of acidic metabolites on the teeth surfaces, enamel demineralization is significantly increased, finally leading to tooth decay. The most prevalent biofilm-related periodontal diseases are gingivitis and periodontitis. When more bacteria become attached, the gum may respond by becoming inflamed. ${ }^{15}$ This process is known as gingivitis. If untreated, bacterial colonization of the periodontal pockets can develop into periodontitis, a severe inflammation of the teeth supporting tissues. ${ }^{16}$ Concurrently, gram-negative pathogens, such as Aggregatibacter actinomycetemcomitans, are enriched within the microbial community. ${ }^{17}$ 

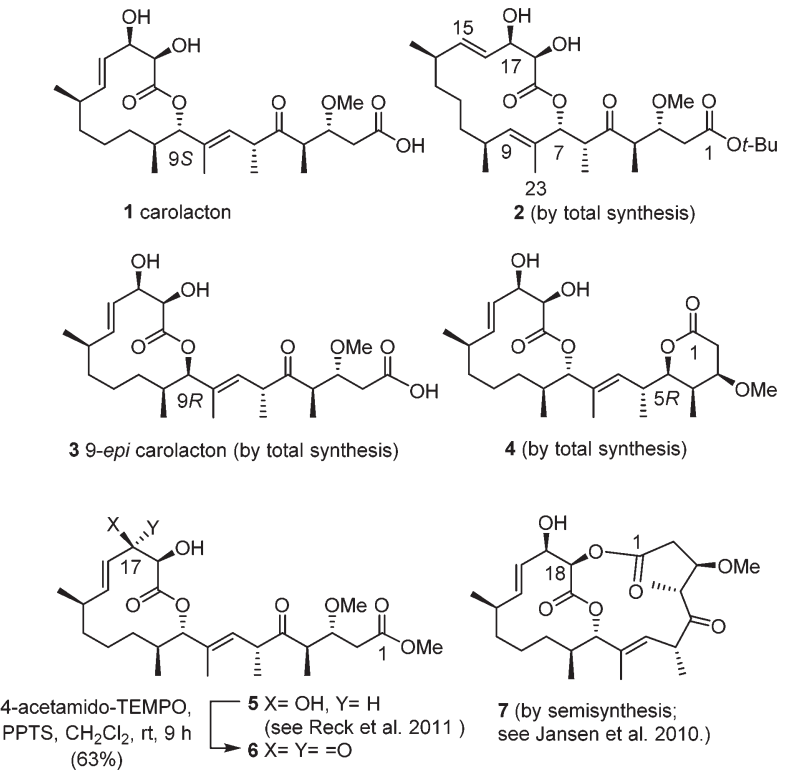

Fig. 1 Carolacton 1 and carolacton derivatives 2-7 studied in this work.

Recently, we discovered and isolated carolacton 1 (Fig. 1) from the extracts of Sorangium cellulosum strain So ce96. ${ }^{18}$ Screening revealed unique biological properties of carolacton 1: at nanomolar concentrations it severely reduces the number of viable cells in biofilms. ${ }^{19,20}$ In particular, biofilms containing the caries- and endocarditis-associated bacterium S. mutans are sensitive to this compound. ${ }^{19,21,22}$

Our first report on carolacton $\mathbf{1}$ as well as its first total synthesis ${ }^{23}$ covered and proved its structure including the assignment of all stereogenic centers. Carolacton $\mathbf{1}$ features a polyketide-type backbone which forms a 12-membered macrolactone with a 1,2-diol moiety with trans orientation in the open-chain conformation. Only recently, a second total synthesis and the preparation of derivatives were disclosed by the group of Phillips. ${ }^{24}$ Both studies paved the way for the preparation of analogues. In this report, we disclose a detailed study of the inhibitory effect of carolacton $\mathbf{1}$ and several carolacton derivatives 2-7 on biofilms comprised of the oral species $S$. mutans, $S$. gordonii, $S$. oralis or A. actinomycetemcomitans. We prepared derivatives 2-7 either by semi- or by total synthesis in order to initiate structure-activity-relationship (SAR) studies. These derivatives differ structurally at several positions from the parent compound carolacton 1. In derivative 3 the stereogenic center at C9 is inverted, while derivatives 2 and 4-7 represent esters or lactones at $\mathrm{C} 1$. We included the methylester $\mathbf{5}$ which had been studied previously. ${ }^{21}$ In derivative 6 the position 17 is oxidized to the keto group, while the main new structural feature in $\delta$-lactone $\mathbf{4}$ is the $(R)$-configured carbinol at C5 instead of the keto group. Derivative 2 is ring-enlarged with respect to the macrolactone to a ring size of 14 atoms (ester via C7 instead of C9) along with the presence of a $t$-butyl ester. Finally, derivative 7 is the result of carolacton macrocyclization between the carboxylate at $\mathrm{C} 1$ and the carbinol at C18.
In this report we describe the synthesis of these carolacton derivatives and show for the first time the effect of carolacton on biofilms of the early colonizers of dental plaque, $S$. gordonii and $S$. oralis, as well as on the periodontopathogen A. actinomycetemcomitans. Moreover, the carolacton analogues enabled us to study the functional importance of various stereogenic centers of carolacton.

\section{Results and discussion}

\section{Synthesis of carolacton derivatives}

Carolacton derivatives 5 and $\mathbf{6}$ were obtained by semisynthetic modification of carolacton 1 through (a) methylation with diazomethane (to yield methyl ester 5) followed by (b) TEMPOmediated oxidation which provided ketone 6 . The synthesis of carolacton derivatives 2-4 started from the advanced intermediates 11a and 11b, respectively, of our published total synthesis (Scheme 1). ${ }^{25}$ These two C9-epimers are formed from

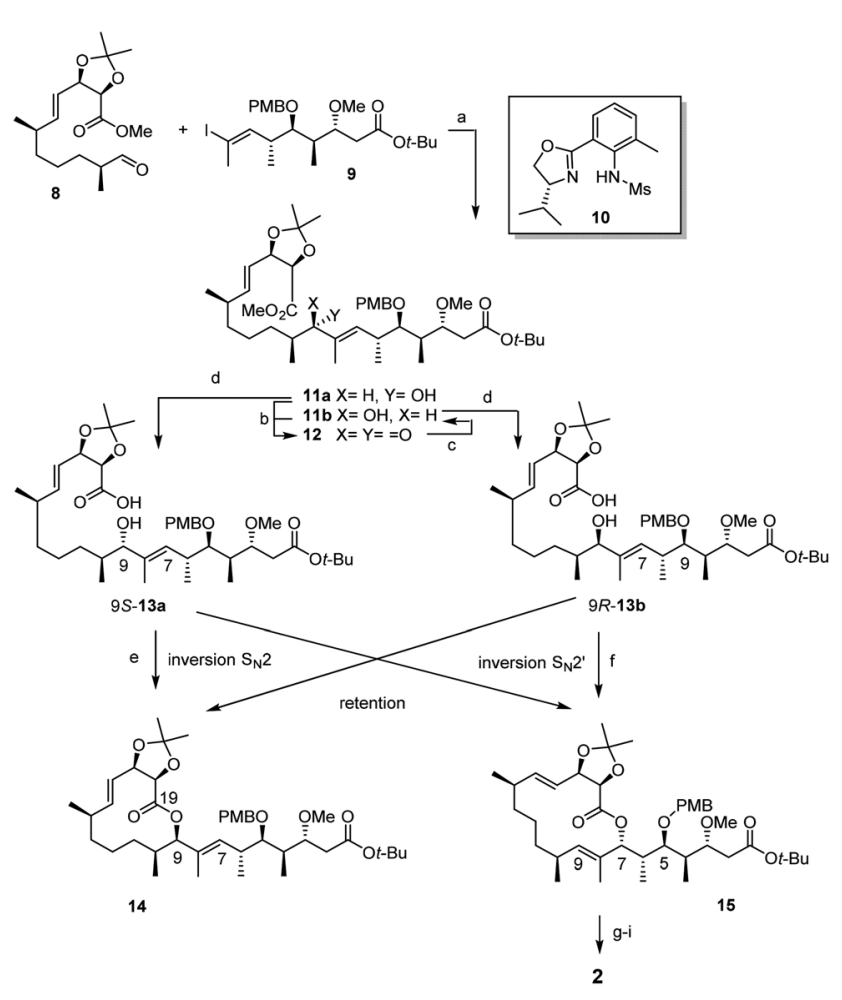

Scheme 1 Last steps towards seco acids 13a and 13b, their macrocyclization by the Mitsunobu reaction and synthesis of carolacton derivative 2. Reagents and conditions: a. i. $(R)-10, \mathrm{CrCl}_{2}$, proton sponge, $\mathrm{MeCN}$, $2 \mathrm{~h}, \mathrm{rt}$; ii. 8, 9, $\mathrm{NiCl}_{2}$ (dppp), $\mathrm{MeCN}$, o/n, rt (96\% for two steps; 11a : 11b = 4.7: 1); b. Dess-Martin periodinane, $\mathrm{CH}_{2} \mathrm{Cl}_{2}, \mathrm{NaHCO}_{3}, 0{ }^{\circ} \mathrm{C}$ to $\mathrm{rt}, 2.5 \mathrm{~h}$ (70\%); c. $\mathrm{NaBH}_{4}, \mathrm{CeCl}_{3} \cdot 7 \mathrm{H}_{2} \mathrm{O}, \mathrm{CH}_{2} \mathrm{Cl}_{2},-50$ to $-30{ }^{\circ} \mathrm{C}, 2 \mathrm{~h}(95 \% ; 11 \mathrm{a}$ : $11 \mathrm{~b}$ = 1:10); d. LiOH (1 M), THF, $\mathrm{H}_{2} \mathrm{O}, \mathrm{rt}, 13 \mathrm{~h}$ (quant.); e. PPh 3 , DIAD, THF, $0{ }^{\circ} \mathrm{C}$ to rt, $5 \mathrm{~h}(76 \% ; 14: 15=1: 1) ; \mathrm{f} . \mathrm{PPh}_{3}, \mathrm{DIAD}, \mathrm{THF}, 0{ }^{\circ} \mathrm{C}$ to rt, $5 \mathrm{~h}$ (87\%; $14: 15=1: 3$ ); g. DDQ, $\mathrm{CH}_{2} \mathrm{Cl}_{2}, \mathrm{pH}=7$ phosphate buffer, $0{ }^{\circ} \mathrm{C}$ to rt, $4 \mathrm{~h}(95 \%) ; \mathrm{h}$. Dess-Martin periodinane, $\mathrm{CH}_{2} \mathrm{Cl}_{2}, \mathrm{NaHCO}_{3}, \mathrm{rt}, 24 \mathrm{~h}$ (62\%); i. PPTS, i-PrOH $/ \mathrm{H}_{2} \mathrm{O} 3: 1,22 \mathrm{~h}, 60{ }^{\circ} \mathrm{C}$ (97\%); (dppp = 1,3-bis(diphenylphosphino)propane, DIAD = diisopropyl azodicarboxylate, $\mathrm{DDQ}=2,3$-dichloro-5,6-dicyanobenzoquinone, $\mathrm{PPTS}=$ pyridinium- $p$ toluenesulfonic acid). 
aldehyde 8 and vinyl iodide 9 by an asymmetric NozakiHiyama-Kishi reaction utilizing ligand $\mathbf{1 0}^{26}$ in excellent yield and with good diastereocontrol (dr 9- $(R)-\mathbf{1 1 a}: 9-(S)-\mathbf{1 1 b}=$ $4.7: 1)$. To preferentially obtain the unnatural $9(S)$-epimer $\mathbf{1 1} \mathbf{b}$, the diastereomeric mixture 11a,b was first oxidized followed by Luche-reduction of ketone 12. Selective hydrolysis of the methyl ester provided the seco acids 13a and 13b, respectively. These were separately subjected to Mitsunobu macrolactonization conditions. Remarkably, in both cases the same two macrolactones were formed. Epimer 13a generated the expected 9- $(S)$-macrolactone 14 through an $\mathrm{S}_{\mathrm{N}} 2$-process as well as the ring enlarged macrocycle $\mathbf{1 5}$ in a $1: 1$ ratio through a $\mathrm{S}_{\mathrm{N}} 2$ '-process.

In the case of the other epimer $\mathbf{1 3 b}$ both macrolactones $\mathbf{1 4}$ and 15 were formed in excellent yield, but in a $1: 3$ ratio in favour of the $\mathrm{S}_{\mathrm{N}} 2^{\prime}$ product 15. Structural analysis of 14 was based on HSQC and HMBC NMR spectroscopy and on the comparison with NMR data collected for the 9-epi derivative of $\mathbf{1 4}$ which is an intermediate in our total synthesis of carolacton 1. For example, compound $\mathbf{1 4}$ shows significant changes in chemical shifts $(\delta)$ for 7-H and 9-H compared to its 9-epimer. The HMBC spectrum of $\mathbf{1 4}$ shows a crosspeak of C19 with 9-H leading to the conclusion that the lactone ring is formed via C9. In case of macrolactone $\mathbf{1 5}$ the HMBC spectrum revealed the rearranged 14-membered ring due to a crosspeak of C19 with 7-H. The $(R)$-configuration at $\mathrm{C} 7$ was deduced in the final derivative 2 by comparing NOE data with molecular modeling data of 2 and its C7-epimer (see ESI $\dagger$ ). Observed NOE contacts across the macrolactone ring between $17-\mathrm{H} / 23-\mathrm{Me}$ as well as 15- $\mathrm{H} / 23-\mathrm{Me}$ correlated to distances below $3 \AA$ for the energy minimized conformation of 2 and to distances above $4 \AA$ for its C7-epimer.

The different behaviour of epimeric allyl alcohols 13a and 13b in macrocyclizations under Mitsunobu conditions is surprising. While 13a behaves in the expected manner, if one assumes activation of the carbinol moiety - the $\mathrm{S}_{\mathrm{N}} 2$ step yielding lactone 14 proceeds with inversion of configuration and the $\mathrm{S}_{\mathrm{N}} 2$ ' step furnishing lactone $\mathbf{1 5}$ with retention of configuration, the rationale for the formation of cyclization products 14 and 15 obtained from allyl alcohol 13b is less clear. We assume that $\mathbf{1 4}$ is generated with retention of configuration from 13b after activation of the carboxylic acid instead of the alcohol. Unlike in the case discussed above, the $\mathrm{S}_{\mathrm{N}} 2^{\prime}$ reaction proceeds with formal inversion of configuration. It has to be noted that there is precedence in $\mathrm{S}_{\mathrm{N}} 2^{\prime}$ reactions for both stereochemical scenarios. A thorough computational modeling analysis on the precursor seco acids and possible transitions states may shed light onto this unusual outcome of the Mitsunobu macrocyclizations.

A short sequence that relates to the endgame of carolacton synthesis leads to macrolactone 2 . It starts with the oxidative removal of the PMB group in lactone 15, followed by DessMartin oxidation of the carbinol at $\mathrm{C} 5$ and final removal of acetonide protection at $\mathrm{C} 17 / \mathrm{C} 18$.

The synthesis of 9-epi carolacton 3 utilized macrolactone 14 which was transformed into carboxylic acid 16 in two steps.
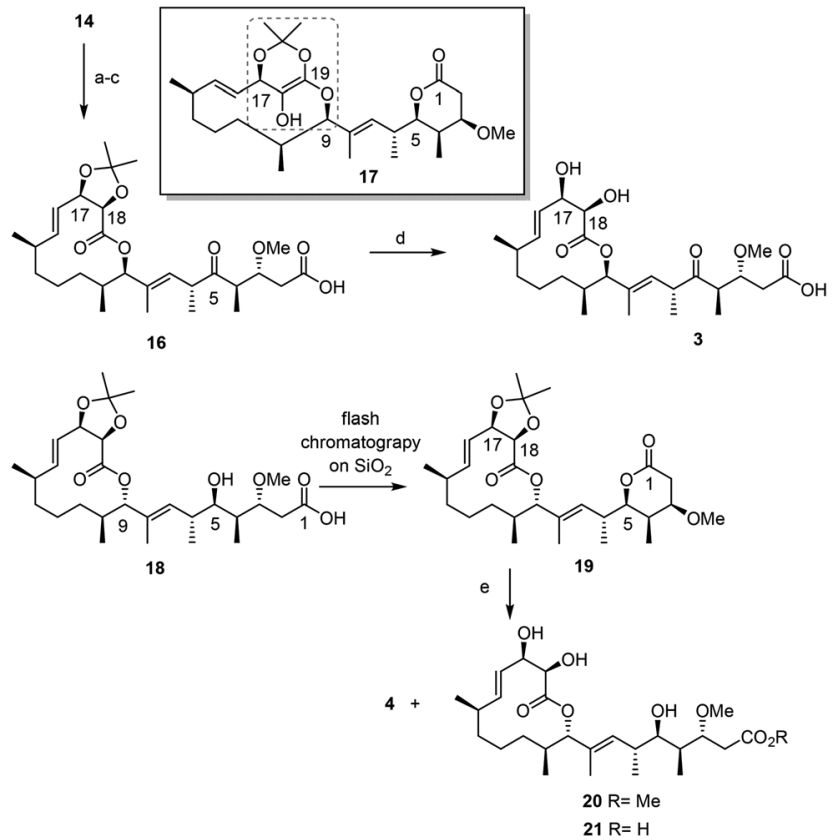

Scheme 2 Synthesis of 9-epi carolacton 3, bislactone 4 and methyl ester $\mathbf{2 0}$ (hydrolysis product $\mathbf{2 1}$ is discussed below). Reagents and conditions: a. i. TESOTf, lutidine, $\mathrm{CH}_{2} \mathrm{Cl}_{2}, 0^{\circ} \mathrm{C}$ to rt, $12 \mathrm{~h}$; ii. TBAF, $10 \mathrm{~min}$; b. DDQ, $\mathrm{CH}_{2} \mathrm{Cl}_{2}, \mathrm{pH}=7$ phosphate buffer, $0{ }^{\circ} \mathrm{C}$ to rt, $1.5 \mathrm{~h}$; c. DessMartin periodinane, $\mathrm{CH}_{2} \mathrm{Cl}_{2}, \mathrm{NaHCO}_{3}, \mathrm{rt}, 2 \mathrm{~h}$ (16: 7\% for three steps; 17: $13 \%$ for three steps); d. PPTS, i-PrOH $/ \mathrm{H}_{2} \mathrm{O}(3: 1), 8 \mathrm{~d}, 68{ }^{\circ} \mathrm{C}(22 \%) ;$ e. PPTS, $\mathrm{MeOH}, \mathrm{rt}, 16 \mathrm{~h}(4: 60 \% ; 20: 35 \%) ;(T E S O T f=$ triethylsilyl trifluoromethane-sulfonate, TBAF $=$ tetra- $n$-butylammonium fluoride).

First the $t$-butyl ester was hydrolyzed using a mild trans-esterification protocol with TESOTf (Scheme 2). ${ }^{27}$ Next the PMB group was removed to provide carbinol 16 in low yield, as several side reactions occurred. One of the undesired products formed during PMB-deprotection was the unusual bislactone 17 which was isolated in 13\% yield starting from 14. Here, undesired $\delta$-lactone formation had occurred as well as a rearrangement of the acetonide moiety at C17/C18. Evidence for the rearrangement to a 1,3-acetonide was collected from the chemical shift of $112 \mathrm{ppm}$ in the ${ }^{13} \mathrm{C}-\mathrm{NMR}$ spectrum combined with a missing proton correlation in the HSQC-spectrum for C18 as well as an unusual high field chemical shift of $114 \mathrm{ppm}$ for the quaternary acetonide carbon.

In fact, during the total synthesis of carolacton (1) we had observed that crude 18 can undergo spontaneous $\delta$-lactonization between the alcohol at C5 and the carboxylic acid at C1, e.g. during flash chromatographic purification which resulted in bislactone 19 (Scheme 2).

Thus, crude alcohol was directly subjected to Dess-Martin oxidation conditions to yield ketone 16 along with 17. Mildly acidic removal of the acetonide moiety in $\mathbf{1 6}$ finalized the synthesis of 9-epi carolacton 3. ${ }^{1} \mathrm{H}$ - and ${ }^{13} \mathrm{C}-\mathrm{NMR}$-spectra of 9-epi carolacton $\mathbf{3}$ and carolacton $\mathbf{1}$ differed from each other especially in the coupling pattern of the protons located within the lactone ring (see ESI $\dagger$ ). 
In addition, we removed the acetonide protection at $\mathrm{C} 17 /$ C18 in bislactone 19 and obtained the two carolacton derivatives 4 and triol 20. The latter is formed by transacylation of the $\delta$-lactone moiety in 19 with the solvent $\mathrm{MeOH}$.

The synthesis of bislactone 7 was reported before ${ }^{18}$ and was achieved by acyl chloride formation of carolacton 1 and regioselective macrolactonization $\left(p-\mathrm{Br}^{-} \mathrm{C}_{6} \mathrm{H}_{4}-\mathrm{COCl}, \mathrm{Et}_{3} \mathrm{~N}, 4-\mathrm{DMAP}\right.$, $\left.\mathrm{CH}_{2} \mathrm{Cl}_{2},-10{ }^{\circ} \mathrm{C}, 2.5 \mathrm{~h} ; 71 \%\right)$. 17-Dehydro carolacton 6 was obtained by selective oxidation at $\mathrm{C} 17$ using the reagent system 4-acetamido-TEMPO in the presence of the other secondary carbinol at $\mathrm{C} 18 .^{28,29}$

\section{Biological activity of carolacton analogues}

To quantitatively compare the activity of carolacton with that of the new synthetic derivatives, live/dead staining of $S$. mutans biofilms was used as a sensitive read-out (Fig. 2A). Both, natural carolacton as well as synthetically obtained carolacton $\mathbf{1}^{25}$ showed the same activity of approximately $60 \%$ biofilm damage even at a concentration as low as $0.05 \mu \mathrm{M}$. These results further confirm that the total synthesis had provided a compound identical to natural carolacton (data not shown). Carolacton derivatives 2-4 and $\mathbf{6}$ had no effect on biofilm viability of $S$. mutans. Especially the results for two derivatives are
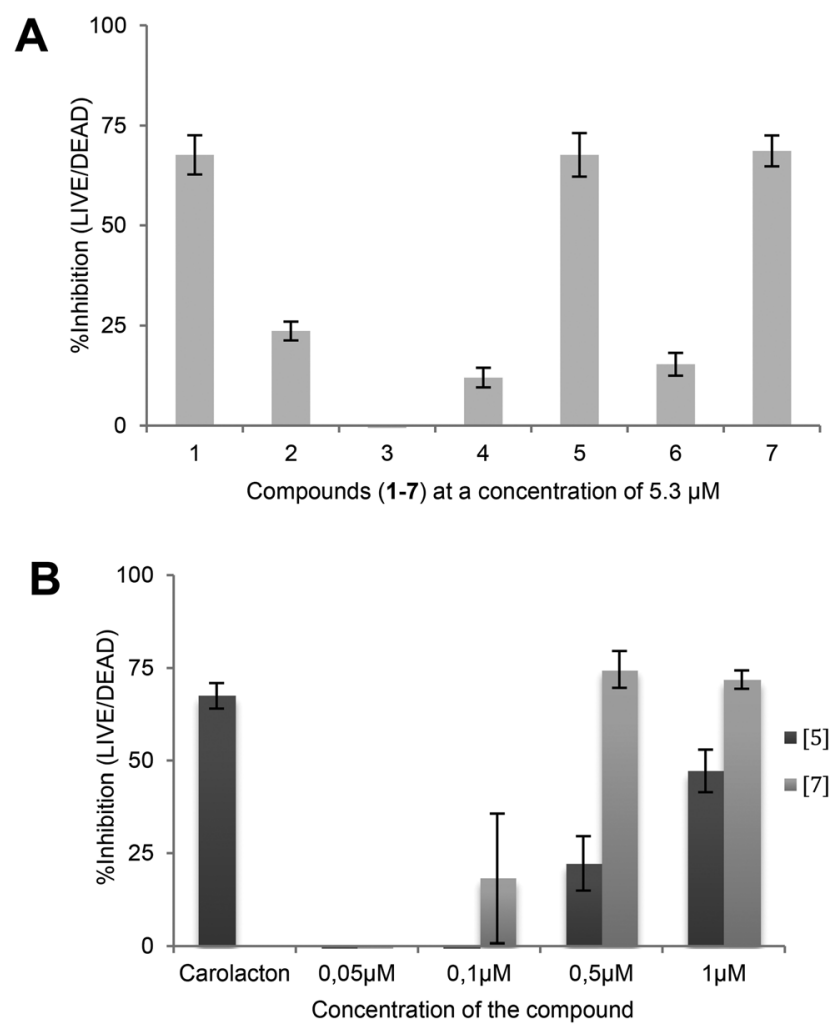

Fig. 2 Inhibition of the viability of biofilm cells by carolacton and synthetic derivatives. (A) Incubation of $S$. mutans biofilms with $5.3 \mu \mathrm{M}$ carolacton 1 or the synthetic compounds 2-7 for $24 \mathrm{~h}$. (B) Biofilms of $S$. mutans were incubated with natural carolacton or the synthetic compounds 5 and 7 at the indicated concentrations for $20 \mathrm{~h}$. noteworthy. The only difference between derivative 3 and carolacton is an inverted stereogenic center at C9 and this small change had a dramatic effect on the biological activity. The loss of activity observed for derivative $\mathbf{6}$ is also noteworthy, because structurally it differs from the biologically active methyl ester 5 only in the oxidation state at C17 which implies that the $(R)$-configured carbinol moiety at C17 is crucial.

Derivatives 5 and 7 had a similar activity as carolacton and were studied in more detail (Fig. 2B). Methyl ester 5 showed a concentration dependent loss in activity as observed previously. ${ }^{21}$ It was not active any more at a concentration of $0.1 \mu \mathrm{M}$. Likewise, bislactone 7 also did not show biofilm inhibitory activity at a concentration of $0.05 \mu \mathrm{M}$. These results can be interpreted in two ways: (a) either the carolacton derivatives have a lower activity due to differences in their interaction with the molecular target of carolacton, or (b) a small amount of native carolacton $\mathbf{1}$ is formed by enzymatic or spontaneous hydrolysis of the ester group in derivatives 5 and 7, respectively, which is responsible for the inhibitory effect.

\section{Reextraction of carolacton and its derivatives after incubation in media and biofilm cultures}

Since carolacton 1 damages $S$. mutans biofilms at nanomolar concentrations, we next had to clarify the origin of activity found for methyl ester 5 and bislactone 7, respectively. First, we tested the chemical stability of the semisynthetic derivatives 5 and 7 in DMSO, the solvent of choice in our assay system. We encountered no formation of carolacton 1 over a period of several days as judged by RP-HPLC-MS (data not shown). Next, we investigated whether derivatives 5 and 7 are hydrolyzed in the medium used for cultivating biofilms, or if enzymatic activity for hydrolyzing the ester groups is present in the bacterial cultures. This was studied by carrying out reextraction (a) from biofilms, (b) from the supernatants after $20 \mathrm{~h}$ of cultivation with $S$. mutans and (c) from the sterile medium after $20 \mathrm{~h}$ of incubation in the absence of bacteria. The results are shown in Fig. 3.

The EIC (extracted ion chromatogram) obtained from RP-HPLC analysis showed traces of carolacton $\mathbf{1}$ (blue curve) in the supernatant of the biofilm that had been treated with methyl ester 5 (orange curve) and bislactone 7 (orange curve) respectively. Carolacton was also detected when biofilms exposed to derivative 7 were re-extracted. The UV spectrum (200-600 nm) is shown in black and the base peak chromatogram is presented in pink for all samples analyzed. The retention time of carolacton 1 determined by UV spectroscopy was in the range of 12.12-12.30 $\mathrm{min}$. The EIC of methyl ester 5 (supernatant) and bislactone 7 (supernatant as well as biofilm) showed signals that correspond to carolacton 1 . The corresponding EIC that was taken from biofilms treated with bislactone 7 showed a very small signal of carolacton 1 . Additionally, the presence of carolacton $\mathbf{1}$ was further confirmed by mass spectrometry (see ESI $\dagger$ ). The concentration of carolacton in the supernatants was quantified by integrating the peak area of the EIC and comparing it with signals from 5 and 7, respect- 
A
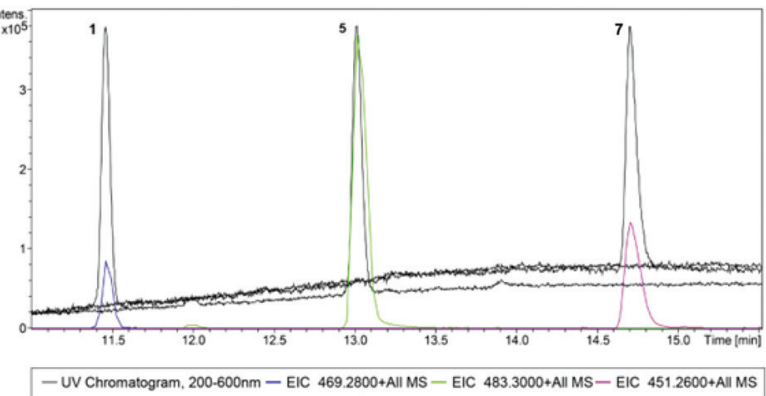

B'

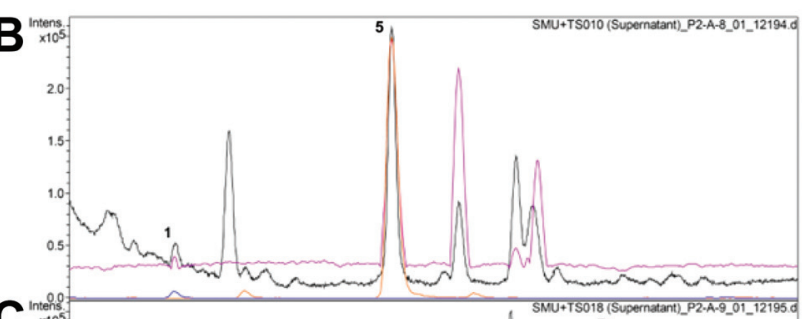

C

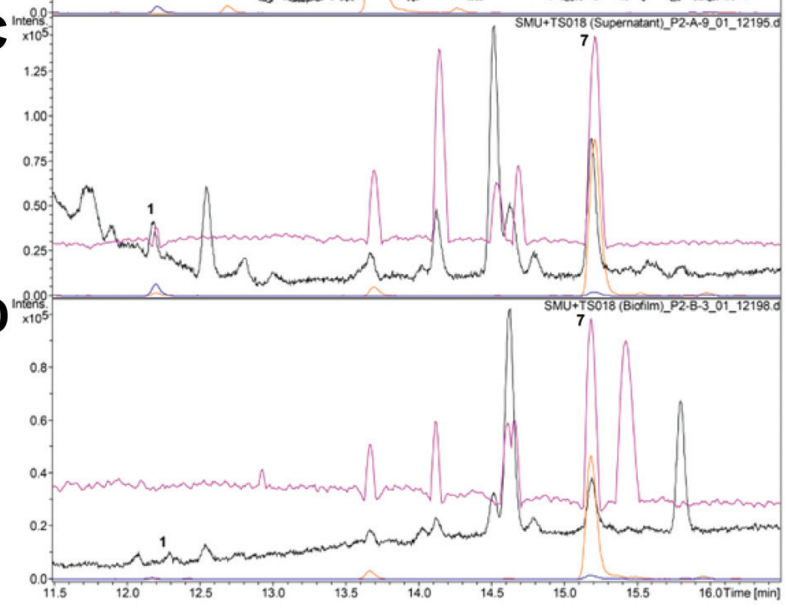

- UV Chromatogram, 200-600nm - BPC+All MS - EIC 469.2800+All MS

-EIC $483.3000+$ All MS (B): EIC $451.2600+$ All MS (C and D)

Fig. 3 Detection of carolacton and synthetic derivatives by RP-HPLC-MS analysis in biofilm cells and biofilm supernatants of Streptococcus mutans after $20 \mathrm{~h}$ of incubation. Panel A shows the RP-HPLC profiles of the pure compounds. The UV chromatogram (black) is shown for all samples in all the panels. The EIC is shown for pure carolacton 1 [blue; mass $(M)=468.58$ ], 5 [green; mass $(M)=482.28$ ] and 7 [pink; mass $(M)=450.26$ )]. Panels $B, C$ and $D$ show the RP-HPLC analysis for extracts from $S$. mutans biofilms treated with 5 (supernatant), 7 (supernatant) and 7 (biofilm) respectively, with the UV and the base peak chromatogram (BPC; Pink). The corresponding mass spectra can be found in the ESI. $\dagger$

ively. These determinations showed that carolacton represented $7.0 \%$ of 5 and $20.7 \%$ of 7 . This corresponds to a concentration of $0.35 \mu \mathrm{M}$ and $1.03 \mu \mathrm{M}$ carolacton 1 , respectively. HRMS analysis showed two $\mathrm{m} / z$ signals of $469.27\left[\mathrm{M}+\mathrm{H}^{+}\right]$and 491.26 $\left[\mathrm{M}^{+} \mathrm{Na}^{+}\right]$that correspond to carolacton 1 (see ESI + ). In contrast, no formation of carolacton was detected in the sterile cultivation medium incubated for $20 \mathrm{~h}$ in the absence of bacteria. While native carolacton could be re-extracted from the supernatants of biofilms treated with methyl ester $\mathbf{5}$, we were not able to re-extract it from the biofilm itself (data not shown), most likely because the concentrations were too low.

From these results, it can be concluded that the pronounced biological effect of carolacton derivatives $\mathbf{5}$ and $\mathbf{7}$ is very likely due to ester hydrolysis and generation of carolacton 1 under the assay conditions. Since both derivatives remained intact in the sterile cultivation medium, the data strongly suggest that the hydrolysis is caused by microbial enzymes.

This assumption was further supported when comparing the activities determined for the two ester derivatives $\mathbf{5}$ and $\mathbf{7}$, with the amount of carolacton that could be re-extracted after biofilm incubation. A starting concentration of $1 \mu \mathrm{M}$ for the methyl ester $\mathbf{5}$ yielded about $70 \mathrm{nM}$ of carolacton $\mathbf{1}$ after hydrolytic cleavage, which corresponds to the transformation of about $7 \%$. This amount resulted in almost maximum biofilm damage. At a concentration of $0.1 \mu \mathrm{M}$ of derivative 5 , which corresponds to $7 \mathrm{nM}$ carolacton $\mathbf{1}$, no biofilm damage was observed, in accordance with the lowest detectable activity at $10 \mathrm{nM}$ determined previously. ${ }^{19}$ The bislactone 7 yielded about $21 \%$ of carolacton at a concentration of $0.1 \mu \mathrm{M}$. This corresponds to $21 \mathrm{nM}$ carolacton which resulted in about halfmaximum biofilm damage as expected. ${ }^{19}$ From these results we conclude that the higher activity of bislactone 7 compared to methyl ester $\mathbf{5}$ is caused by the larger fraction of carolacton 1 that is formed from the former derivative by biological hydrolysis.

Likewise, we studied the chemical stability of the two ester derivatives 4 and 6 under the assay conditions by analyzing samples after reextraction from (a) biofilms, (b) the supernatants after $20 \mathrm{~h}$ of cultivation with S. mutans and (c) the sterile medium after $20 \mathrm{~h}$ of incubation. If ester hydrolysis occurs for those compounds as well, this would prove that the corresponding free acids are inactive like the parent compounds 4 and 6. UPLC-ESI-MS and MS/MS analyses of extracts from cultures incubated with lactone $\mathbf{4}$ indeed revealed the presence of the starting material $\mathbf{4}$ along with the hydrolysis product 21 (see Scheme 2). The degree of hydrolysis was estimated by integration of the ion chromatograms (sodium adducts of carboxylic acid $\mathbf{2 1}$ and lactone 4) and 20\% were found in the biofilm sample (a), $7 \%$ in the supernatant (b) and $40 \%$ in the sterile medium (c). The identity of the carboxylic acid 21 was verified by high resolution MS and MS-MSexperiments. From these results we conclude that neither the $\delta$-lactone 4 nor the corresponding free acid $\mathbf{2 1}$ exert inhibitory activity towards biofilms of $S$. mutans and consequently the keto group at position 5 in carolacton $\mathbf{1}$ is biologically essential. Extracts collected from biofilms incubated with ketone $\mathbf{6}$ were difficult to analyze, most likely due to the highly reactive enone moiety. Indeed, most of the starting material had decomposed and only traces of keto derivative $\mathbf{6}$ were found as judged by UPLC-MS analysis.

\section{Effect of carolacton on biofilms of S. gordonii, S. oralis and Aggregatibacter actinomycetemcomitans}

Carolacton 1 affects biofilms that are formed by streptococci in different ways. Assessment of biofilm morphology and viability 
by confocal laser scanning microscopy (CLSM) after $24 \mathrm{~h}$ of culturing uncovered a reduction of viable cells within $S$. mutans biofilms as described previously. This was indicated by an increased PI uptake that resulted in predominantly redfluorescent bacterial cells (Fig. 4C). CLSM images of $S$. gordonii and $S$. oralis biofilms mainly showed green fluorescent bacteria, indicating that no membrane damage was induced by carolacton treatment (Fig. 4B and D). However, the morphology of carolacton treated biofilms showed large differences to untreated biofilms. For $S$. gordonii, a more voluminous structure could be observed, with predominantly vertically orientated cell chains, while the control biofilms displayed more tightly packed biofilm architecture (Fig. 4B). For $S$. oralis, the CLSM analyses revealed massively reduced biofilm formation in the presence of carolacton 1 . Thus, the cell density on the substratum surface was considerably reduced. A. actinomycetemcomitans biofilms showed no membrane damage as judged by CLSM. A small change in bacterial cell morphology was observed: in the presence of carolacton $\mathbf{1}$, the rod-like $A$. actinomycetemcomitans cells appeared to be
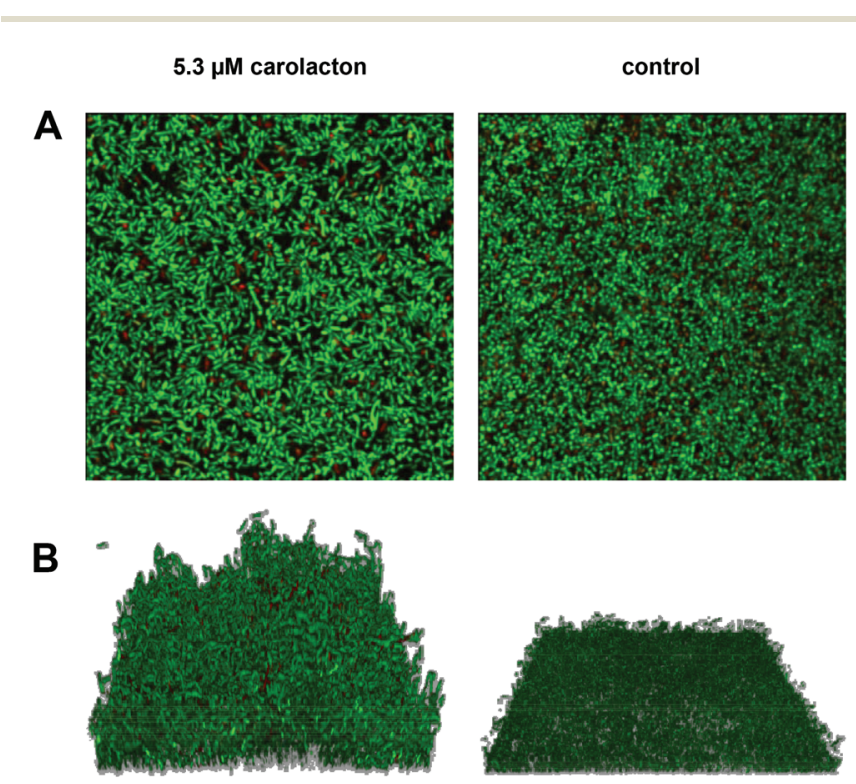

C
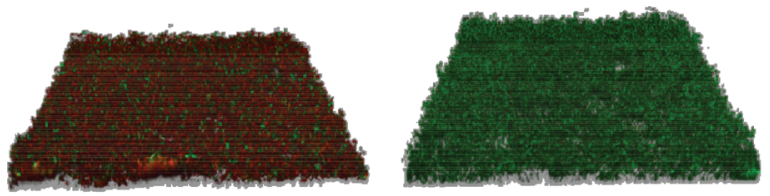

D
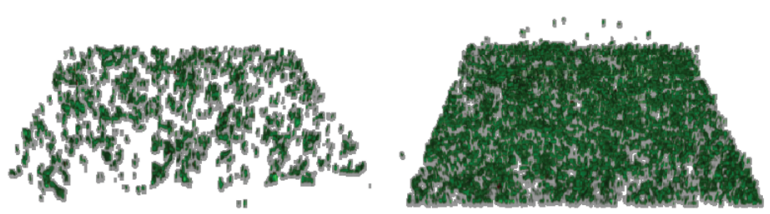

Fig. 4 Influence of carolacton on biofilm morphology and viability. Biofilm analysis by CLSM after $24 \mathrm{~h}$ incubation with and without carolacton: (A) Aggregatibacter actinomycetemcomitans; (B-D) 3D reconstructed images of (B) Streptococcus gordonii, (C) S. mutans and (D) S. oralis. extended (Fig. 4A). The data confirmed these results and showed that indeed carolacton had only a very weak effect on the membrane damage of $S$. gordonii and $S$. oralis biofilms, which was moreover strongly dependent on the density of the inoculum culture and the age of the biofilm (see $\operatorname{ESI} \dagger$ ). However, carolacton inhibited growth of $S$. oralis biofilms (see ESI $\dagger$ ). To determine if the observed changes in biofilm morphology might be caused by a different growth behavior of the cells, carolacton treated streptococci were inspected under the fluorescence microscope (see ESI, Fig. S6†). All streptococci showed elongated cell chains. This had been observed for $S$. mutans before ${ }^{19}$ and was most striking for $S$. gordonii cultures. These cell chains might be the reason for the voluminous biofilms of $S$. gordonii treated with carolacton. $S$. oralis cultures also formed elongated cells when treated with carolacton, although to a lesser extent. The data confirm that the primary effect of carolacton is a defect in cell wall synthesis and cell division. The strong membrane damage observed in $S$. mutans biofilms is a secondary effect caused by the acidification of the environment during biofilm growth and is eliminated in a buffered medium as described. ${ }^{21}$

\section{Localized release}

Because of the activity of carolacton 1 against oral microorganisms, including the caries pathogen $S$. mutans, it might be possible to prevent biofilm formation locally. Carolacton was therefore included in dental filling material, and the viability of $S$. mutans biofilms grown on this material was shown to be reduced. The small amounts of carolacton needed did not impact the mechanical properties of the material. ${ }^{22}$ Here, we found another possibility to control the release of carolacton to the microorganisms:

Remarkably, ester derivatives 5 and 7 that lack the free carboxylate group still show biofilm inhibitory activity in a similar range as carolacton 1 . As demonstrated in this report for bislactone 7 and methylester 5 the activity is due to hydrolysis of the lactone ring attached to $\mathrm{C}-18$ by bacterial enzymes and in both cases carolacton $\mathbf{1}$ is formed. $\delta$-Lactone derivative $\mathbf{4}$ and methyl ester $\mathbf{6}$ also hydrolyze under the assay conditions but neither the parent compounds nor the hydrolysis products exerted biofilm inhibitory activity. In the former case this is due to the lack of the essential keto group at C5. In the latter case 17-dehydro carolacton would be the hydrolysis product.

As a result of these studies derivatives 5 and 7 can be viewed as prodrugs that are activated by $S$. mutans through enzymes that hydrolyze the ester at C-1. Consequently, the microorganisms initiate their own death. It is noteworthy that similar strategies have been applied rationally ${ }^{30}$ in biomedical applications. For example, polymeric dental surfaces have been activated by triggering the release of bioactive compounds or drugs using enzymes. ${ }^{31}$

\section{Experimental procedures}

The biological test procedures and NMR spectroscopic data as well as signal assignments of all intermediates and final 
products are listed in the ESI. $\dagger$ Carolacton derivative $\mathbf{5}$ was reported before. ${ }^{21}$ The synthesis of advanced intermediates 8 and $\mathbf{9}$ and derivatives 11a,b and $\mathbf{1 2}$ are described in ref. 22 and carolacton derivative $\mathbf{6}$ in ref. 28. Ligand $\mathbf{1 0}$ was prepared according to Kishi et $a l^{32}$ Carolacton derivative 7 was first reported by Jansen et al. ${ }^{18}$ The biological test procedures are described in detail in the ESI. $\dagger$

\section{Preparation of ketone 12}

To a solution of an epimeric mixture of alcohols 11a/11b (100 mg, $139 \mu \mathrm{mol}, 1$ equiv.) in $\mathrm{CH}_{2} \mathrm{Cl}_{2}(4 \mathrm{~mL})$ a mixture of Dess-Martin periodinane (100 mg, $0.24 \mathrm{mmol}, 1.7$ equiv.) and $\mathrm{NaHCO}_{3}$ (100 mg, $1.18 \mathrm{mmol}, 8.5$ equiv.) were added under air at $0{ }^{\circ} \mathrm{C}$. The reaction mixture was warmed to $\mathrm{rt}$ and stirred for $1 \mathrm{~h}$. After addition of an aqueous, saturated $\mathrm{Na}_{2} \mathrm{~S}_{2} \mathrm{O}_{3}$-solution the resulting mixture was stirred vigorously for $40 \mathrm{~min}$. The layers were separated and the aqueous layer was extracted four times with $\mathrm{CH}_{2} \mathrm{Cl}_{2}$. The combined, organic layers were dried over $\mathrm{MgSO}_{4}$ and concentrated under reduced pressure. Purification by flash chromatography (petroleum ether:ethyl acetate $=4: 1)$ provided ketone $12(89 \mathrm{mg}, 124 \mu \mathrm{mol}, 89 \%)$ as a colorless oil. $[\alpha]_{\mathrm{D}}^{25}=-15.1^{\circ}\left(c=0.65, \mathrm{CH}_{2} \mathrm{Cl}_{2}\right) ; R_{\mathrm{f}}=0.33$ (petroleum ether: ethyl acetate $=3: 1$ ); HRMS (ESI): $\mathrm{m} / \mathrm{z}$ for $\mathrm{C}_{41} \mathrm{H}_{64} \mathrm{O}_{10} \mathrm{Na}[\mathrm{M}+\mathrm{Na}]^{+}$: calculated 739.4397, found 739.4377 .

\section{Lactonization of epimeric alcohols $13 \mathrm{a}$ and $13 \mathrm{~b}$}

Route A: to a solution of alcohol $(S)-11 a(53 \mathrm{mg}, 75 \mu \mathrm{mol}$, 1 equiv.) in THF ( $3 \mathrm{ml})$ an aqueous solution of $1 \mathrm{M} \mathrm{LiOH}$ $(0.27 \mathrm{~mL})$ and water $(0.3 \mathrm{~mL})$ were added at $\mathrm{rt}$. The solution was stirred for $15 \mathrm{~h}$ and aqueous $1 \mathrm{M} \mathrm{HCl}(0.36 \mathrm{~mL})$ was added. After addition of saturated, aqueous $\mathrm{NH}_{4} \mathrm{Cl}$ and ethyl acetate the layers were separated. The aqueous layer was extracted three times with ethyl acetate. The combined, organic layers were washed with brine, dried over $\mathrm{MgSO}_{4}$ and concentrated under reduced pressure. Seco acid 9-(S)-13a was obtained as a colorless oil and was used for the next step without further purification (53 mg, quant). $R_{\mathrm{f}}=0.30\left(\mathrm{CH}_{2} \mathrm{Cl}_{2}\right.$ : $\mathrm{MeOH}=20: 1$ ).

To a solution of triphenylphosphine $(305 \mathrm{mg}, 1.17 \mathrm{mmol}$, 15 equiv.) in THF (20 mL) was added diisopropyl azodicarboxylate $(0.23 \mathrm{~mL}, 1.13 \mathrm{mmol}, 15$ equiv.) at rt. The solution was cooled to $0{ }^{\circ} \mathrm{C}$ and a solution of the above mentioned seco acid 9-(S)-13a (53 mg, $75 \mu \mathrm{mol}, 1$ equiv.) in THF $(20 \mathrm{~mL})$ was added via syringe pump within $2 \mathrm{~h}$. The reaction mixture was allowed to warm to $\mathrm{rt}$ and stirred for $3 \mathrm{~h}$. The reaction mixture was filtered through a pad of Celite ${ }^{\mathrm{TM}}$ and washed with an aqueous phosphate buffer solution ( $\mathrm{pH}$ 7). Layers were separated and the aqueous layer was extracted three times with diethyl ether. The combined organic layers were washed with brine, dried over $\mathrm{MgSO}_{4}$ and concentrated under reduced pressure. Purification by flash chromatography (petroleum ether: ethyl acetate $=8: 1)$ provided lactones 15 (19 mg, $28 \mu \mathrm{mol}, 37 \%$; fraction 1) and 9-epi-14 (20 mg, $29 \mu \mathrm{mol}, 39 \%$; fraction 2) as colorless oils in 76\% total yield ( $\mathrm{dr}=1: 1)$.

Route B: following the experimental procedure described above using alcohol $(R)$-11b (47 mg, 67 mol, 1 equiv.) as start- ing material instead provided lactones $15(30 \mathrm{mg}, 44 \mu \mathrm{mol}$, 66\%; fraction 1) and 14 (15 mg, $29 \mu \mathrm{mol}, 21 \%$; fraction 2$)$ as colorless oils in $87 \%$ total yield $(\mathrm{dr}=3: 1) .14:[\alpha]_{\mathrm{D}}^{19}=+1.0^{\circ}(c=$ 2.0, $\mathrm{CH}_{2} \mathrm{Cl}_{2}$ ); $R_{\mathrm{f}}=0.27$ (petroleum ether : ethyl acetate $=5: 1$ ); HRMS (ESI): $m / z$ for $\mathrm{C}_{40} \mathrm{H}_{63} \mathrm{O}_{9}[\mathrm{M}+\mathrm{H}]^{+}$: calculated 687.4472, found 687.4476; 15: $[\alpha]_{\mathrm{D}}^{19}=-17.9^{\circ}\left(c=0.34, \mathrm{CH}_{2} \mathrm{Cl}_{2}\right) ; R_{\mathrm{f}}=0.28$ (petroleum ether : ethyl acetate $=5: 1$ ); HRMS (ESI): $\mathrm{m} / \mathrm{z}$ for $\mathrm{C}_{40} \mathrm{H}_{63} \mathrm{O}_{9}[\mathrm{M}+\mathrm{H}]^{+}$: calculated 687.4472, found 687.4476.

\section{Synthesis of carolacton derivative 2}

To a mixture of lactone 15 (16.4 mg, $24 \mu \mathrm{mol}, 1$ equiv.) in $\mathrm{CH}_{2} \mathrm{Cl}_{2}(2.5 \mathrm{~mL})$ and aqueous phosphate $\mathrm{pH} 7$ buffer solution (0.3 mL, $10 \mathrm{wt} \%)$ a solution of 2,3-dichloro-5,6-dicyano-1,4benzoquinone (10 mg, $47 \mu \mathrm{mol}, 2$ equiv.) in $\mathrm{CH}_{2} \mathrm{Cl}_{2}(1 \mathrm{~mL})$ was added within $1 \mathrm{~min}$ at $0{ }^{\circ} \mathrm{C}$. The solution was stirred for $4 \mathrm{~h}$. After addition of an aqueous sodium bicarbonate solution sodium sulfite ( $\sim 100 \mathrm{mg}$ ) was added and the resulting yellow solution was stirred for $10 \mathrm{~min}$. Layers were separated and the aqueous layer was extracted three times with ethyl acetate. The combined organic layers were washed with brine, dried over $\mathrm{MgSO}_{4}$, filtered and concentrated under reduced pressure. After column chromatography (petroleum ether : ethyl acetate $=10: 1 \rightarrow 5: 1)$ alcohol $\mathbf{S} 1$ was obtained as a colorless oil (12.9 mg, $23 \mu \mathrm{mol}, 95 \%)$. Alcohol S1: $[\alpha]_{\mathrm{D}}^{25}=-5.8^{\circ}(c=1.2$, $\mathrm{CH}_{2} \mathrm{Cl}_{2}$ ); $R_{\mathrm{f}}=0.14$ (petroleum ether : ethyl acetate $=5: 1$ ); HRMS (ESI): $m / z$ for $\mathrm{C}_{32} \mathrm{H}_{54} \mathrm{O}_{8} \mathrm{Na}[\mathrm{M}+\mathrm{Na}]^{+}$: calculated 589.3716 , found 589.3712 .

To a mixture of alcohol $\mathbf{S 1}(12.9 \mathrm{mg}, 23 \mu \mathrm{mol}, 1$ equiv.) in $\mathrm{CH}_{2} \mathrm{Cl}_{2}(5 \mathrm{~mL})$ a mixture of Dess-Martin periodinane $(150 \mathrm{mg}$, 0.35 mmol, 16 equiv.) and $\mathrm{NaHCO}_{3}$ (100 mg, $1.2 \mathrm{mmol}$, 50 equiv.) was added at $0{ }^{\circ} \mathrm{C}$. The reaction mixture was allowed to warm to rt and stirred for $24 \mathrm{~h}$. Then, an aqueous, saturated $\mathrm{Na}_{2} \mathrm{~S}_{2} \mathrm{O}_{3}$-solution was added. The mixture was vigorously stirred for $1 \mathrm{~h}$. Layers were separated and the aqueous layer was extracted three times with dichloromethane. The combined, organic layers were dried over $\mathrm{MgSO}_{4}$, filtered and concentrated under reduced pressure. Purification by flash chromatography (petroleum ether: ethyl acetate $=5: 1$ ) provided ketone $\mathbf{S} 2$ as a colorless oil (7.9 mg, $14 \mu \mathrm{mol}, 62 \%)$. Ketone S2: $[\alpha]_{\mathrm{D}}^{27}=-55.5^{\circ}\left(c=0.75, \mathrm{CH}_{2} \mathrm{Cl}_{2}\right) ; R_{\mathrm{f}}=0.26$ (petroleum ether: ethyl acetate $=5: 1$ ); HRMS (ESI): $m / z$ for $\mathrm{C}_{32} \mathrm{H}_{52} \mathrm{O}_{8} \mathrm{Na}[\mathrm{M}+\mathrm{Na}]^{+}$: calculated 587.3560 , found 587.3569 .

To a solution of ketone $\mathbf{S} 2(5.0 \mathrm{mg}, 9 \mu \mathrm{mol}, 1$ equiv.) in degassed (4 fpt cycles) methanol $(2.0 \mathrm{~mL})$ PPTS $(2 \mathrm{mg}, 8 \mu \mathrm{mol}$, 1 equiv.) was added at rt under argon atmosphere. After the solution was stirred at $60{ }^{\circ} \mathrm{C}$ for $22 \mathrm{~h}$ water was added $(0.5 \mathrm{~mL})$. A stream of nitrogen was passed over the solution until the volume had concentrated to a half $(\sim 1 \mathrm{~mL})$. The remaining solution was directly subjected to HPLC purification (C18 isis; run time $60 \mathrm{~min}$; ratio $\mathrm{H}_{2} \mathrm{O}: \mathrm{MeOH}=45: 55$ for 5 min then $45: 55 \rightarrow 0: 100$ in $\left.45 \mathrm{~min} ; 2 t_{\mathrm{r}}=34.2 \mathrm{~min}\right)$. Diol 2 was obtained as a colourless solid $(4.5 \mathrm{mg}, 9 \mu \mathrm{mol}, 97 \%)$. Carolacton derivative $2:[\alpha]_{\mathrm{D}}^{25}=-24.3^{\circ}\left(c=0.21, \mathrm{CH}_{2} \mathrm{Cl}_{2}\right) ; R_{\mathrm{f}}=0.16$ (petroleum ether: ethyl acetate $=2: 1$ ); HRMS (ESI): $\mathrm{m} / \mathrm{z}$ for $\mathrm{C}_{29} \mathrm{H}_{48} \mathrm{O}_{8} \mathrm{Na}[\mathrm{M}+\mathrm{Na}]^{+}$: calculated 547.3247, found 547.3248. 


\section{Synthesis of ketone 16 and byproduct 17}

To a solution of lactone $14(29.5 \mathrm{mg}, 43 \mu \mathrm{mol}, 1$ equiv.) in $\mathrm{CH}_{2} \mathrm{Cl}_{2}(3 \mathrm{~mL})$ was added 2,6-lutidine $(0.1 \mathrm{~mL}, 0.9 \mathrm{mmol}$, 20 equiv.) and triethylsilyl trifluoromethanesulfonate $(0.1 \mathrm{~mL}$, $0.43 \mathrm{mmol}, 10$ equiv.) at $0{ }^{\circ} \mathrm{C}$. The solution was allowed to warm to rt and stirred for another $16 \mathrm{~h}$. Then, the solution was recooled to $0{ }^{\circ} \mathrm{C}$ and an aqueous, saturated ammonium chloride solution was added. Layers were separated and the aqueous layer was extracted three times with ethyl acetate. The combined, organic layers were washed with brine, dried over $\mathrm{MgSO}_{4}$, filtered and the solvent was removed under reduced pressure. The crude product was dissolved in $\mathrm{CH}_{2} \mathrm{Cl}_{2}(10 \mathrm{~mL})$ and a mixture of TBAF ( $60 \mathrm{mg}, 0.2 \mathrm{mmol}, 4$ equiv.) in $\mathrm{CH}_{2} \mathrm{Cl}_{2}$ $(5 \mathrm{~mL})$ was added at $0{ }^{\circ} \mathrm{C}$. After the solution had been stirred for $1 \mathrm{~h}$ at $0{ }^{\circ} \mathrm{C}$ an aqueous, saturated ammonium chloride solution was added. Layers were separated and the aqueous layer was extracted three times with ethyl acetate. The combined, organic layers were washed with brine, dried over $\mathrm{MgSO}_{4}$, filtered and the solvent was removed under reduced pressure. Purification by flash chromatography $\left(\mathrm{CH}_{2} \mathrm{Cl}_{2}\right.$ : $\mathrm{MeOH}=30: 1$ ) provided an inseparable mixture of carboxylic acid $\mathbf{S} 3$ and tetrabutylammonium impurities $(23.2 \mathrm{mg}) ; R_{\mathrm{f}}=$ $0.16\left(\mathrm{CH}_{2} \mathrm{Cl}_{2}: \mathrm{MeOH}=30: 1\right)$.

The above mentioned crude product (S3: approx. $15.5 \mathrm{mg}$ as judged by ${ }^{1} \mathrm{H}-\mathrm{NMR}, 25 \mu \mathrm{mol}, 1$ equiv.) in $\mathrm{CH}_{2} \mathrm{Cl}_{2}(2 \mathrm{~mL})$ was taken up in an aqueous phosphate $\mathrm{pH} 7$ buffer solution $(0.3 \mathrm{~mL}, 10 \mathrm{wt} \%)$ and a solution of 2,3-dichloro-5,6-dicyano1,4-benzoquinone (11.6 mg, $50 \mu \mathrm{mol}, 2$ equiv.) in $\mathrm{CH}_{2} \mathrm{Cl}_{2}$ $(1.5 \mathrm{~mL})$ was added within $1 \mathrm{~min}$ at $0{ }^{\circ} \mathrm{C}$. The solution was stirred for $1.5 \mathrm{~h}$. The completion of the reaction was monitored by $\operatorname{TLC}\left(R_{\mathrm{f}}=0.33 \rightarrow 0.20 ; \mathrm{CH}_{2} \mathrm{Cl}_{2}: \mathrm{MeOH}=20: 1\right)$. After addition of a saturated, aqueous $\mathrm{NaHCO}_{3}$-solution $(3 \mathrm{~mL})$ layers were separated and the aqueous layer was extracted five times with ethyl acetate. The combined, organic layers were washed with brine, dried over $\mathrm{MgSO}_{4}$, filtered and concentrated under reduced pressure. The dark red residue (hydroxycarboxylate $\mathbf{S 4})$ was dissolved in $\mathrm{CH}_{2} \mathrm{Cl}_{2}(6 \mathrm{~mL})$ and a mixture of Dess-Martin periodinane ( $64 \mathrm{mg}, 0.15 \mathrm{mmol}, 6$ equiv.) and $\mathrm{NaHCO}_{3}$ (34 mg, $0.65 \mathrm{mmol}, 16$ equiv.) were added at $0{ }^{\circ} \mathrm{C}$. The reaction mixture was allowed to warm to $\mathrm{rt}$ and stirred for $2 \mathrm{~h}$. Then, an aqueous, saturated $\mathrm{Na}_{2} \mathrm{~S}_{2} \mathrm{O}_{3}$-solution was added. The mixture was vigorously stirred for $20 \mathrm{~min}$. Layers were separated and the aqueous layer was extracted five times with ethyl acetate. The combined, organic extracts were washed with brine, dried over $\mathrm{MgSO}_{4}$ and concentrated under reduced pressure. In a first purification step by flash chromatography $\left(\mathrm{CH}_{2} \mathrm{Cl}_{2}: \mathrm{MeOH}=20: 1\right)$ bislactone 17 was separated from ketone 16. Bislactone $\mathbf{1 7}$ was purified by a second flash chromatography (petroleum ether : ethyl acetate $=2: 1$ ) to yield a colorless oil (2.8 mg, $5.8 \mu \mathrm{mol}, 13 \%$ for 3 steps). Ketone $\mathbf{S 4}$ was purified by HPLC (C18 isis; run time $60 \mathrm{~min}$; ratio $\mathrm{H}_{2} \mathrm{O}: \mathrm{MeOH}$ $=80: 20$ for $5 \mathrm{~min}$ then $80: 20 \rightarrow 0: 100$ in $50 \mathrm{~min} ; t_{\mathrm{r}}=$ $50.0 \mathrm{~min})$ and was collected as a colorless oil $(1.5 \mathrm{mg}, 3 \mu \mathrm{mol}$, $7 \%$ for 3 steps $)$. Ketone 16: $[\alpha]_{\mathrm{D}}^{25}=-67.3^{\circ}\left(c=0.15, \mathrm{CH}_{2} \mathrm{Cl}_{2}\right)$; $R_{\mathrm{f}}=0.14$ (petroleum ether $:$ ethyl acetate $=20: 1$ ); HRMS (ESI): $m / z$ for $\mathrm{C}_{28} \mathrm{H}_{44} \mathrm{O}_{8} \mathrm{Na}\left[\mathrm{M}+\mathrm{Na}^{+}\right.$: calculated 531.2934, found 531.2939; 17: $[\alpha]_{\mathrm{D}}^{20}=-40.0^{\circ}\left(c=0.13, \mathrm{CH}_{2} \mathrm{Cl}_{2}\right) ; R_{\mathrm{f}}=0.66$ (petroleum ether: ethyl acetate $=20: 1$ ); HRMS (ESI): $\mathrm{m} / \mathrm{z}$ for $\mathrm{C}_{28} \mathrm{H}_{44} \mathrm{O}_{7} \mathrm{Na}[\mathrm{M}+\mathrm{Na}]^{+}$: calculated 515.2985, found 515.2990.

\section{Synthesis of 9-epi-carolacton 3}

To a solution of ketone $\mathbf{S} 4(1.5 \mathrm{mg}, 3 \mu \mathrm{mol}, 1$ equiv.) in degassed (5 fpt cycles) isopropyl alcohol $(1.2 \mathrm{~mL})$ and water (0.4 mL) PPTS ( $4 \mathrm{mg}, 15 \mu \mathrm{mol}, 6$ equiv.) was added at rt. The solution was stirred at $68^{\circ} \mathrm{C}$ for 8 days and then cooled to rt. The reaction mixture was concentrated to half of the original volume (about $0.8 \mathrm{~mL}$ ) by passing a stream of nitrogen over the solution. The remaining material was directly purified by HPLC (C18 isis; run time $60 \mathrm{~min}$; ratio $\mathrm{H}_{2} \mathrm{O}: \mathrm{MeOH}=20: 80 \rightarrow$ $0: 100$ in $55 \mathrm{~min}$; 9-epi-carolacton $3 t_{\mathrm{r}}=37.8 \mathrm{~min}$ and starting material S4 $\left.t_{\mathrm{r}}=46.1 \mathrm{~min}\right)$. This procedure was repeated with the reisolated starting material $\mathbf{S 4}$. The products obtained from both reactions were combined and 9-epi-carolacton 3 was obtained as a colorless oil $(0.3 \mathrm{mg}, 1 \mu \mathrm{mol}, 22 \%)$. 9-epi-Carolacton 3: $[\alpha]_{\mathrm{D}}^{19}=-43.0^{\circ}\left(c=0.03, \mathrm{CH}_{2} \mathrm{Cl}_{2}\right) ; R_{\mathrm{f}}=0.36\left(\mathrm{CH}_{2} \mathrm{Cl}_{2}\right.$ : $\mathrm{MeOH}=10: 1$ ); HRMS (ESI): $m / z$ for $\mathrm{C}_{25} \mathrm{H}_{40} \mathrm{O}_{8} \mathrm{Na}[\mathrm{M}+\mathrm{Na}]^{+}$: calculated 491.2621 , found 491.2618 .

\section{Synthesis $\delta$-lactone 4 and methyl ester 20}

To a solution of bislactone $19(1.5 \mathrm{mg}, 3 \mu \mathrm{mol}, 1$ equiv.) in degassed (4 fpt cycles) methanol $(2.0 \mathrm{~mL})$ PPTS $(3 \mathrm{mg}$, $12 \mu \mathrm{mol}, 4$ equiv.) was added at rt. Water was added $(50 \mu \mathrm{L})$ after the solution had been stirred at rt for $16 \mathrm{~h}$. The reaction mixture was concentrated to about half of its original volume (about $1 \mathrm{~mL}$ ) by passing a stream of nitrogen over the solution. The remaining material was directly purified by HPLC (C18 isis; run time $60 \mathrm{~min}$; ratio $\mathrm{H}_{2} \mathrm{O}: \mathrm{MeOH}=45: 55$ for $5 \mathrm{~min}$ then $45: 55 \rightarrow 0: 100$ in $45 \min ; 4 t_{\mathrm{r}}=27.6 \mathrm{~min} \& 20 t_{\mathrm{r}}=$ $30.1 \mathrm{~min})$. Diol 4 was obtained as a colorless solid $(0.8 \mathrm{mg}$, $2 \mu \mathrm{mol}, 60 \%)$ and triol 20 as a viscous gel $(0.5 \mathrm{mg}, 1 \mu \mathrm{mol}$, $35 \%)$. $\delta$-Lactone 4: $[\alpha]_{\mathrm{D}}^{20}=-8.8^{\circ}\left(c=0.08, \mathrm{CH}_{2} \mathrm{Cl}_{2}\right) ; R_{\mathrm{f}}=0.15$ (petroleum ether : ethyl acetate $=1: 1$ ); HRMS (ESI): $\mathrm{m} / \mathrm{z}$ for $\mathrm{C}_{25} \mathrm{H}_{40} \mathrm{O}_{7} \mathrm{Na}[\mathrm{M}+\mathrm{Na}]^{+}$: calculated 475.2672, found 475.2660; methyl ester 20: $[\alpha]_{\mathrm{D}}^{20}=-40.0^{\circ}\left(c=0.05, \mathrm{CH}_{2} \mathrm{Cl}_{2}\right) ; R_{\mathrm{f}}=0.21$ (petroleum ether: ethyl acetate $=1: 1$ ); $\operatorname{HRMS}(\mathrm{ESI}): \mathrm{m} / \mathrm{z}$ for $\mathrm{C}_{26} \mathrm{H}_{44} \mathrm{O}_{8} \mathrm{Na}[\mathrm{M}+\mathrm{Na}]^{+}$: calculated 507.2943, found 507.2945.

\section{Synthesis of methyl ester 5}

To a solution of carolacton 1 (20.9 mg, $44.6 \mu \mathrm{mol}, 1$ equiv.) in $\mathrm{CH}_{2} \mathrm{Cl}_{2} / \mathrm{MeOH} \quad(10: 1,11 \mathrm{~mL})$ a solution of trimethylsilyldiazomethane in hexane $\left(0.15 \mathrm{~mL}, c=2 \mathrm{~mol} \mathrm{~L} \mathrm{~L}^{-1}\right.$, $0.30 \mathrm{mmol}, 6.7$ equiv.) was added dropwise at rt. Ethyl acetate (6 drops) was added after the reaction mixture had been stirred at rt for $1 \mathrm{~h}$. The reaction mixture was concentrated under reduced pressure and the residue was purified by HPLC (C18 isis; run time $60 \mathrm{~min}$; ratio $\mathrm{H}_{2} \mathrm{O}: \mathrm{MeOH}=80: 20$ for 5 min then $80: 20 \rightarrow 0: 100$ in $50 \mathrm{~min} ; 5 t_{\mathrm{r}}=45 \mathrm{~min}$ ) to obtain methyl ester 5 as a colorless oil (17.4 mg, $36.1 \mu \mathrm{mol}, 81 \%)$; methyl ester 5: $[\alpha]_{\mathrm{D}}^{20}=-171.4^{\circ}\left(c=0.5, \mathrm{CH}_{2} \mathrm{Cl}_{2}\right) ; R_{\mathrm{f}}=0.57$ $\left(\mathrm{CH}_{2} \mathrm{Cl}_{2}: \mathrm{MeOH}=10: 1\right)$; HRMS (ESI): $m / z$ for $\mathrm{C}_{26} \mathrm{H}_{42} \mathrm{O}_{8} \mathrm{Na}$ $[\mathrm{M}+\mathrm{Na}]^{+}$: calculated 505.2777, found 505.2773. 


\section{Synthesis of ketone 6}

To a solution of methyl ester 5 (11.1 mg, $23.0 \mu \mathrm{mol}, 1$ equiv.) in $\mathrm{CH}_{2} \mathrm{Cl}_{2}(1 \mathrm{~mL})$ 4-acetamido-2,2,6,6-tetramethylpiperidine-1oxyl (11.9 mg, 56.0 $\mu \mathrm{mol}, 2.4$ equiv.) and PTSA (10.6 mg, $57 \mu \mathrm{mol}, 2.5$ equiv.) were added at $0{ }^{\circ} \mathrm{C} . \mathrm{CH}_{2} \mathrm{Cl}_{2}(5 \mathrm{~mL})$ and a saturated $\mathrm{NaHCO}_{3}$-solution were added after the reaction mixture had been stirred at $\mathrm{rt}$ for $9 \mathrm{~h}$. Layers were separated and the aqueous layer was extracted three times with $\mathrm{CH}_{2} \mathrm{Cl}_{2}$. The combined, organic layers were washed with brine, dried over $\mathrm{MgSO}_{4}$, filtered and the solvent was removed under reduced pressure. Purification by flash chromatography (petroleum ether: ethyl acetate $=2: 1$ ) provided ketone 6 as a yellow oil which was further purified by HPLC (C18 isis; run time $60 \mathrm{~min}$; ratio $\mathrm{H}_{2} \mathrm{O}: \mathrm{MeOH}=80: 20$ for 5 min then $80: 20$ $\rightarrow 0: 100$ in $50 \mathrm{~min} ; 6 t_{\mathrm{r}}=44 \mathrm{~min}$ ) to obtain ketone 6 as a colorless oil (7.0 mg, $14.6 \mu \mathrm{mol}, 63 \%$, dr $>20: 1)$; ketone 6 : $[\alpha]_{\mathrm{D}}^{20}=$ $-159.8^{\circ}\left(c=0.4, \mathrm{CH}_{2} \mathrm{Cl}_{2}\right) ; R_{\mathrm{f}}=0.52$ (petroleum ether : ethyl acetate = 1:1); HRMS (ESI): $m / z$ for $\mathrm{C}_{26} \mathrm{H}_{40} \mathrm{O}_{8} \mathrm{Na}[\mathrm{M}+\mathrm{Na}]^{+}$: calculated 503.2620, found 503.2621.

\section{Conclusions}

This investigation reports on new carolacton derivatives including ring-enlarged ones obtained by total synthesis. In this context, we studied regio- and stereochemical aspects of the macrocyclization under Mitsunobu conditions in detail. Our preliminary structure-activity relationship studies demonstrates that there is currently no modification that retains the activity of the molecule, including the methylation of the carbon side-chain. A small change in the stereochemistry of C9 is sufficient to render the molecule inactive. These data show that the interaction between carolacton and its unknown biological target molecule must be highly specific. The data also confirm that the primary effect of carolacton treatment is a defect in cell division, the extent of which varies between species of streptococci, but which is also observed, albeit weakly, in the gram-negative pathogen A. actinomycetemcomitans.

\section{Acknowledgements}

This work has been carried out as an integral part of the BIOFABRICATION FOR NIFE Initiative, which is financially supported by the ministry of Lower Saxony and the Volkswagen Stiftung (NIFE is the Lower Saxony Center for Biomedical Engineering, Implant Research and Development, a joint translational research center of the Hannover Medical School, the Leibniz University Hannover, the University of Veterinary Medicine Hannover and the Laser Center Hannover.) Further support for Priyanka Premnath was provided by the State of Lower Saxony through the MINAS program. Michael Reck was funded by the German Ministry for Education and Research (BMBF) in the program e:bio (grant number 031 A299).

\section{Notes and references}

1 R. M. Donlan and J. W. Costerton, Clin. Microbiol. Rev., 2002, 15, 167-193.

2 M. R. Parsek and P. K. Singh, Annu. Rev. Microbiol., 2003, 57, 677-701.

$3 \mathrm{H}$. Anwar and J. W. Costerton, Antimicrob. Agents Chemother., 1990, 34, 1666-1671.

4 S. M. Moskowitz, J. M. Foster, J. Emerson and J. L. Burns, J. Clin. Microbiol., 2004, 42, 1915-1922.

5 J. N. Anderl, M. J. Franklin and P. S. Stewart, Antimicrob. Agents Chemother., 2000, 44, 1818-1824.

6 C. Human, Microbiome Project, Nature, 2012, 486, 207214.

7 T. Chen, W. H. Yu, J. Izard, O. V. Baranova, A. Lakshmanan and F. E. Dewhirst, Database, 2010, 2010, baq013.

8 J. Li, E. J. Helmerhorst, C. W. Leone, R. F. Troxler, T. Yaskell, A. D. Haffajee, S. S. Socransky and F. G. Oppenheim, J. Appl. Microbiol., 2004, 97, 13111318.

9 S. Filoche, L. Wong and C. H. Sissons, J. Dent. Res., 2010, 89, 8-18.

10 J. Kreth, J. Merritt and F. Qi, DNA Cell Biol., 2009, 28, 397403.

11 P. D. Marsh and D. A. Devine, J. Clin. Periodontol., 2011, 38 (Suppl 11), 28-35.

12 P. E. Petersen and H. Ogawa, Periodontol. 2000, 2012, 60, 15-39.

13 W. J. Loesche, Microbiol. Rev., 1986, 50, 353-380.

14 G. H. Bowden, J. Dent. Res., 1990, 69, 1205-1210.

15 A. Mariotti, Ann. Periodontol., 1999, 4, 7-19.

16 T. F. Flemmig, Ann. Periodontol., 1999, 4, 32-38.

17 M. T. Pollanen, A. Paino and R. Ihalin, Int. J. Mol. Sci., 2013, 14, 17221-17237.

18 R. Jansen, H. Irschik, V. Huch, D. Schummer, H. Steinmetz, M. Bock, T. Schmidt, A. Kirschning and R. Müller, Eur. J. Org. Chem., 2010, 1284-1289.

19 B. Kunze, M. Reck, A. Dötsch, A. Lemme, D. Schummer, H. Irschik, H. Steinmetz and I. Wagner-Döbler, BMC Microbiol., 2010, 10, 199.

20 B. Kunze, I. Wagner-Döbler, H. Irschik and H. Steinmetz, Germany Pat, WO2009030773 A1, 2009.

21 M. Reck, K. Rutz, B. Kunze, J. Tomasch, S. K. Surapaneni, S. Schulz and I. Wagner-Döbler, J. Bacteriol., 2011, 193, 5692-5706.

22 C. Apel, A. Barg, A. Rheinberg, G. Conrads and I. WagnerDöbler, Dent. Mater., 2013, 29, 1188-1199.

23 T. Schmidt and A. Kirschning, Angew. Chem., Int. Ed., 2012, 124, 1087-1091.

24 M. S. Hallside, R. S. Brzozowski, W. M. Wuest and A. J. Phillips, Org. Lett., 2014, 16, 1148-1151.

25 T. Schmidt and A. Kirschning, Angew. Chem., Int. Ed., 2012, 51, 1063-1066.

26 K. Kobayashi, Y. Fujii, I. Hayakawa and H. Kigoshi, Org. Lett., 2011, 13, 900-903. 
27 C. B. Lee, Z. Wu, F. Zhang, M. D. Chappell, S. J. Stachel, T. C. Chou, Y. Guan and S. J. Danishefsky, J. Am. Chem. Soc., 2001, 123, 5249-5259.

28 J. Gebauer and S. Blechert, J. Org. Chem., 2006, 71, 20212025.

29 T. J. Hunter and G. A. O’Doherty, Org. Lett., 2002, 4, 44474450.
30 M. Ait-Tihyaty, Z. Rachid, A. L. Larroque-Lombard and B. J. Jean-Claude, Invest. New Drugs, 2013, 31, 14091423.

31 J. Hu, G. Zhang and S. Liu, Chem. Soc. Rev., 2012, 41, 59335949.

32 Z. K. Wan, H. W. Choi, F. A. Kang, K. Nakajima, D. Demeke and Y. Kishi, Org. Lett., 2002, 4, 4431-4434. 